\title{
Fimbrial-Specific Monoclonal Antibody-Based ELISA for European Potato Strains of Erwinia chrysanthemi and Comparison to PCR
}

\author{
U. Singh, C. M. Trevors, and S. H. De Boer, Centre of Expertise for Potato Diseases, Canadian Food Inspection \\ Agency, Charlottetown, PE, C1A 5T1; and J. D. Janse, Plant Protection Service, 6700HC Wageningen, The Neth- \\ erlands
}

\begin{abstract}
Singh, U., Trevors, C. M., De Boer, S. H., and Janse, J. D. 2000. Fimbrial-specific monoclonal antibody-based ELISA for European potato strains of Erwinia chrysanthemi and comparison to PCR. Plant Dis. 84:443-448.

A murine hybridoma cell line, named 6A6, was developed to produce monoclonal antibodies for serological detection of European potato strains of Erwinia chrysanthemi. The monoclonal antibodies were of the immunoglobulin $\mathrm{G}_{2 \mathrm{~b}}$ type and were shown to react with a fimbrial antigen by immuno-gold electron microscopy, and with the fibrillin protein by Western blotting. In enzyme-linked immunosorbent assay (ELISA), the monoclonal antibody reacted with all but two strains of E. chrysanthemi isolated from potato. One non-reactive strain originated from Australia and therefore was likely a different biovar, and the other strain was of unknown origin. The monoclonal antibody also reacted with 20 out of 36 strains of E. chrysanthemi isolated from hosts other than potato. A triple-antibody ELISA test utilizing monoclonal antibody 6A6 successfully detected $E$. chrysanthemi in infected potato stems and tubers but sensitivity was limited to about $10^{7} \mathrm{CFU} / \mathrm{ml}$, compared to a sensitivity of $10^{3} \mathrm{CFU} / \mathrm{ml}$ for a polymerase chain reaction test using published primers directed to the pectate lyase gene.
\end{abstract}

Additional keywords: blackleg, detection, pili, slow wilt, stem wet rot

Erwinia chrysanthemi is a gram-negative bacterial plant pathogen which causes rot diseases of many plant species that are important as agricultural and ornamental crops. It is increasingly being recognized as an important pathogen of potato, having been reported on potato in Australia (4), Japan (26), South Africa (24), and western Europe $(17,28)$. In the Netherlands, the disease on potato is known as stem wet rot (27) whereas, in the United Kingdom, it is referred to as slow wilt (25), akin to slow wilt of carnation, also caused by E. chrysanthemi (16). Slow wilt of potato has, on occasion, been severe in the United Kingdom, where more than $50 \%$ of plants wilted (25). Although E. chrysanthemi is not known to cause disease in potato in Canada or the United States, Cappaert et al. (2) in Oregon reported the isolation of E. chrysanthemi from water and potato foliage, including some diseased stems. However, the Oregon isolates were characterized inadequately to confirm unequivocally their identity as E. chrysan-

Corresponding author: S. H. De Boer

E-mail: deboers@em.agr.ca

Accepted for publication 13 December 1999.

Publication no. D-2000-0209-01R

This article is in the public domain and not copyrightable. It may be freely reprinted with customary crediting of the source. The American Phytopathological Society, 2000. themi and tests were not conducted to show pathogenicity on potato.

In Australia, E. chrysanthemi persists in and spreads from surface water sources and is primarily a tuber disease, causing decay of the seed and progeny tubers. In other geographic areas, the disease is reported primarily as a wilt disease of potato foliage. In stem infections, the disease is characterized by decay of the pith tissue followed by brown to black discoloration of the basal stem region, resembling blackleg caused by E. carotovora subsp. atroseptica. Leaves on affected stems may wilt, or turn yellowish and rigid, depending on weather conditions. The disease favors warm field temperatures and affected stems often recover from their symptoms, appearing healthy, when weather conditions become cooler. In the Netherlands, field observations suggest that blackleglike symptoms are caused by E. chrysanthemi during warm summers and by $E$. carotovora subsp. atroseptica during cool summers (J. D. Janse, unpublished observation).

Some strains of E. chrysanthemi are relatively host specific and the species can be differentiated into biovars based on physiological and biochemical characteristics $(8,23)$. Isolates from potato in Australia are primarily of biovar 3, whereas isolates from western European countries mostly belong to biovars 5 and 7. Biochemical differences among strains within biovars have been recorded (12). Strains of
E. chrysanthemi can also be differentiated on the basis of serological specificity of lipopolysaccharide (O antigen) and flagellar ( $\mathrm{H}$ antigen) antigens, but such groupings do not correlate with biovar type $(12,22)$.

The biological and epidemiological importance of biovar and serological differences are not well understood, although differences in maximum growth temperature of strains may be of ecological significance. Janse and Scheepens (13) found that strains isolated from crops grown in tropical or subtropical regions, as well as under warm greenhouse conditions, were able to grow at $39^{\circ} \mathrm{C}$ and showed pectolytic activity at $37^{\circ} \mathrm{C}$, whereas strains from hosts growing in more temperate environments did not. Strains in biovars 1 and 7 and some strains of biovar 5 were of the lowtemperature type. Most potato strains from temperate areas also differ from tropical strains in restriction fragment length polymorphism patterns, biovar type, and pectic enzyme profile (1), as well as optimum growth temperature (13). The taxonomic position of the potato strains as a host-specific subgroup remains tenuous, however.

The economic importance of E. chrysanthemi on potato in temperate countries has not been adequately assessed. Nevertheless, because its spread to geographic areas that are currently free from this pathogen is undesirable, rapid and accurate diagnostic tools are required for its detection and identification. Efforts in the Netherlands to detect $E$. chrysanthemi by serological tests have been frustrated by the cross-reaction of both polyclonal and monoclonal antibodies with soil-inhabiting pseudomonads. Van der Wolf et al (29) showed that cross reactivity was a result of antigenically similar lipopolysaccharide epitopes being shared by E. chrysanthemi and specific strains of soil pseudomonads.

As an alternative to serological assays, polymerase chain reaction (PCR) tests have been developed using primers directed to the pectate lyase gene (19). However, enzyme-linked immunosorbent assay (ELISA) is often preferred over PCR because the latter test is costly and time-consuming for testing large numbers of samples. Furthermore, having both serological and nucleic-acid-based tests available for a microorganism is useful for identification of a pathogen in a plant sample without the need for isolation and characterization of 
the causal agent. For quarantine and certification purposes, where the objective is to index for freedom from pathogens rather than diagnosing the etiology of a disease, direct isolation may be difficult, if not impossible. Sensitive detection of a patho- genic bacterium can be achieved by laboratory techniques in the absence of disease symptoms.

In this study, we developed an ELISA procedure utilizing a new monoclonal antibody to strains of $E$. chrysanthemi isolated

Table 1. Strains of Erwinia chrysanthemi tested in enzyme-linked immunosorbent assay (ELISA) with monoclonal antibody $6 \mathrm{~A} 6$ and in polymerase chain reaction (PCR)

\begin{tabular}{|c|c|c|c|c|c|}
\hline $\begin{array}{l}\text { Strain, } \\
\text { isolates }^{\mathrm{a}}\end{array}$ & $\begin{array}{c}\text { Biovar } \\
\text { (if known) }\end{array}$ & Origin $^{b}$ & Host & $\begin{array}{l}\text { Absorbance } \\
\text { in ELISA }\end{array}$ & $\mathbf{P C R}^{\mathrm{d}}$ \\
\hline Potato & $\ldots$ & & & & \\
\hline IPO645 & $\cdots$ & Australia & Solanum tuberosum & 0.929 & + \\
\hline IPO647 & $\ldots$ & Australia & S. tuberosum & 0.027 & + \\
\hline IPO655 & $\ldots$ & NK & S. tuberosum & 0.007 & + \\
\hline IPO766 & $\ldots$ & NK & S. tuberosum & 1.456 & + \\
\hline NCPPB3529 & $\ldots$ & United Kingdom & S. tuberosum & 3.160 & + \\
\hline NCPPB3530 & $\ldots$ & United Kingdom & S. tuberosum & 1.640 & + \\
\hline NCPPB3710 & $\ldots$ & United Kingdom & S. tuberosum & 2.260 & + \\
\hline NCPPB3881 & $\ldots$ & United Kingdom & S. tuberosum & 1.090 & + \\
\hline PD226 & 7 & Netherlands & S. tuberosum & 0.898 & ND \\
\hline PD482 & 5 & Netherlands & S. tuberosum & 1.053 & ND \\
\hline PD483 & 7 & Netherlands & S. tuberosum & 0.701 & ND \\
\hline PD581 & 7 & Netherlands & S. tuberosum & 0.751 & ND \\
\hline PD676 & 7 & Netherlands & S. tuberosum & 0.145 & ND \\
\hline PD678 & $\ldots$ & Netherlands & S. tuberosum & 0.437 & ND \\
\hline PD684 & $\ldots$ & Netherlands & S. tuberosum & 1.330 & + \\
\hline PD719 & $\ldots$ & Netherlands & S. tuberosum & 1.470 & + \\
\hline PD1008 & 5 & Netherlands & S. tuberosum & 0.967 & + \\
\hline PD1405 & 1 & Netherlands & S. tuberosum & 1.615 & ND \\
\hline PD1406 & 5 & Netherlands & S. tuberosum & 1.267 & ND \\
\hline \multicolumn{6}{|l|}{ Non-potato } \\
\hline PD1619 & 3 & Netherlands & Achmea fasciata & 1.652 & ND \\
\hline PD1268 & 3 & Netherlands & Aglaomena sp. & 0.042 & ND \\
\hline PD862 & 3 & Netherlands & Ananas comosus & 1.311 & ND \\
\hline PD823 & 1 & Netherlands & Begonia bertinii & 0.061 & ND \\
\hline PD852 & 3 & Netherlands & Brassica chinenesis & 0.896 & ND \\
\hline PD1233 & 5 & Netherlands & Chichorium intybus & 0.678 & ND \\
\hline PD1238 & 1 & Netherlands & C. intybus & 1.100 & ND \\
\hline PD687 & 5 & Netherlands & Chrysanthemum morifolium & 0.026 & ND \\
\hline PD1086 & 3 & Netherlands & Ctenanthe lubbersii & 1.599 & ND \\
\hline LMG2488 & $\ldots$ & Netherlands & Dahlia sp. & 2.200 & + \\
\hline LMG2474 & $\ldots$ & United States & Daucus carota & 0.006 & + \\
\hline PD844 & 5 & Netherlands & D. carota & 0.067 & ND \\
\hline IPO661 & 5 & NK & Dianthus sp. & 0.087 & + \\
\hline LMG2485 & $\ldots$ & United Kingdom & D. caryophyllus & 2.085 & + \\
\hline PD718 & 1 & Netherlands & D. caryophyllus & 0.465 & ND \\
\hline PD846 & 5 & Netherlands & D. caryophyllus & 0.442 & ND \\
\hline IPO652 & 1 & United States & Dieffenbachia amoena & 0.263 & + \\
\hline IPO653 & 1 & NK & D. picta & 2.540 & + \\
\hline PD690 & 2 & Netherlands & Dieffenbachia sp. & 1.499 & ND \\
\hline IPO657 & 3 & United States & Euphorbia pulcherrima & 0.003 & + \\
\hline PD1461 & 3 & Netherlands & Freesia sp. & 0.527 & ND \\
\hline PD826 & 3 & NK & Gymnocalicium mihanovichii & 1.015 & ND \\
\hline PD1462 & 3 & Netherlands & Hippeastrum sp. & 1.459 & ND \\
\hline PD677 & 7 & Netherlands & Kalanchoe blossfeldiana & 0.797 & ND \\
\hline PD1325 & 7 & Netherlands & K. tropicana & 1.175 & ND \\
\hline IPO662 & 6 & NK & Musa paradisica & 0 & + \\
\hline PD864 & 4 & Netherlands & M. paradisica & 0.048 & ND \\
\hline PD866 & 3 & Netherlands & Oryza sativa & 0.016 & ND \\
\hline IPO654 & 2 & United States & Parthenium argentatum & 0.006 & + \\
\hline PD845 & 6 & Netherlands & $P$. argentatum & 0.007 & ND \\
\hline IPO658 & 4 & United States & Philodendron panduriforme & 0.005 & + \\
\hline PD861 & 3 & Netherlands & Saintpaulia ionantha & 0.280 & ND \\
\hline PD552 & 3 & Netherlands & Scindapsus pictus & 0 & ND \\
\hline IPO659 & 4 & United States & Syngonium podophyllum & 0.002 & ND \\
\hline PD689 & 3 & Netherlands & Zea mays & 0.676 & ND \\
\hline PD1659 & 6 & Sweden & Surface water & 0.056 & ND \\
\hline
\end{tabular}

${ }^{\text {a }}$ Cultures were obtained from the following: IPO = Research Institute for Plant Protection, Wageningen; LMG = Laboratorium voor Microbiologie, Rijksuniversiteit, Gent; PD = Plant Protection Service, Bacteriology Section Culture Collection, Wageningen.

${ }^{\mathrm{b}} \mathrm{NK}=$ not known.

${ }^{\mathrm{c}}$ ELISA tests were considered positive if the absorbance readings were three times that of negative control values.

${ }^{\mathrm{d}} \mathrm{ND}=$ not done.

from potato in Europe. Sensitivity and specificity of the serological procedure was compared with a PCR test.

\section{MATERIALS AND METHODS}

Bacterial strains. Strains of E. chrysanthemi used in this study are listed in Table 1. Strains of heterologous bacteria included in this study for comparative purposes are listed in Table 2. Bacteria were grown in trypticase soy broth (TSB) or on trypticase soy agar (TSA) for $24 \mathrm{~h}$ at $28^{\circ} \mathrm{C}$ and stored at $-70^{\circ} \mathrm{C}$ in $10 \%$ glycerol. $E$. chrysanthemi strain NCPPB3530 was used for antibody production and screening of monoclonal antibodies.

Antibody production. A polyclonal antiserum was produced to E. chrysanthemi in a New Zealand white rabbit using glutaraldehyde-fixed cells as immunogen. Five intramuscular immunizations were made at 2-week intervals, after which the serum fraction was collected from blood obtained by cardiac puncture.

Monoclonal antibodies were produced from hybridomas made using standard procedures. Splenocytes from mice immunized by intraperitoneal injection of glutaraldehyde-fixed cells were fused with FOX-NY cells using 50\% polyethylene glycol and 5\% dimethyl sulphoxide as fusogens. Hybridomas were selectively grown in Dulbecco's modified Eagles Medium supplemented with hypoxanthine, aminopterin, and thymidine, and screened by ELISA as described below. Hybridomas were screened against $E$. chrysanthemi and E. carotovora subsp. carotovora at the first testing stage to detect monoclonal antibodies with discriminatory specificity. Selected hybridomas were cloned by limiting dilution and tested against the strains listed in Tables 1 and 2. Isotype of the most useful monoclonal antibody was determined using a commercial kit (Boehringer Mannheim, Laval, PQ, Canada).

ELISA. Standard ELISA procedures (18) were used for testing pure cultures of bacteria and plant tissue. For screening hybridomas for monoclonal antibodies, 24h-old cells from pure bacterial cultures were washed and suspended in $0.01 \mathrm{M}$ phosphate-buffered saline (PBS, pH 7.2) and the concentration adjusted to an optical density (OD) of 1.0 at $620 \mathrm{~nm}$. Antigen was bound directly to wells of microtiter plates by incubating $100 \mu \mathrm{l}$ of cell suspension, diluted $1: 1$ in $0.1 \mathrm{M}$ carbonate buffer ( $\mathrm{pH}$ 9.6), in each well at $4^{\circ} \mathrm{C}$ overnight. Hybridoma fluid was tested directly after blocking wells with $5 \%$ skim milk. Reactive antibodies were detected using goatantimouse antibodies conjugated to alkaline phosphatase and p-nitrophenol phosphate at $0.5 \mathrm{mg} / \mathrm{ml}$ in $1 \mathrm{M}$ diethanolamine buffer ( $\mathrm{pH} 9.8)$. All incubations for the ELISA protocol were for $1 \mathrm{~h}$ at $37^{\circ} \mathrm{C}$, except the blocking step, which was done for only $30 \mathrm{~min}$. Absorbances were read at 
$405 \mathrm{~nm}$ with a plate reader after 45 to 60 min of incubation of the substrate.

For screening selected monoclonal antibodies against additional bacterial strains and plant samples, a triple-antibody ELISA protocol was used, in which antigen was captured by the polyclonal antiserum precoated onto plates at a 1:5000 dilution of raw serum in $0.1 \mathrm{M}$ carbonate buffer $(\mathrm{pH}$ 9.6). Bacterial cell suspensions and plant extracts were prepared as a 1:1 ratio in sample buffer containing (per liter) $2 \mathrm{~g}$ of $\mathrm{KH}_{2} \mathrm{PO}, 11.5 \mathrm{~g}$ of $\mathrm{Na}_{2} \mathrm{HPO}_{4}, 0.14 \mathrm{~g}$ of disodium EDTA, $0.02 \mathrm{~g}$ of thimerosal, and $0.2 \mathrm{~g}$ of lysozyme (14). The ELISA test was completed in the same manner as described above, and samples were considered positive if the absorbance readings were three times that of negative control wells.

Immunofluorescence. Immunofluorescence tests were conducted on pure cultures using the indirect method of De Boer (5).

Western blotting. Whole bacterial cellprotein profiles and fimbrial preparations, made according to the procedure of Heckels and Virji (11), were analysed, after boiling for $5 \mathrm{~min}$, by polyacrylamide gel electrophoresis using $10 \%$ polyacrylamide in a Protean II mini-gel apparatus (Bio-Rad Laboratories Ltd, Mississagua, ON, Canada) run at $100 \mathrm{~V}$, and subsequently were stained with Coomassie blue. Proteins from unstained gels were electrophoretically transferred to nitrocellulose membrane at $150 \mathrm{~V}$ using buffer $(\mathrm{pH} 8.3)$ consisting of $25 \mathrm{mM}$ Tris-HCl, $192 \mathrm{mM}$ glycine, and $20 \%$ methanol. The transblot was probed with monoclonal antibody $6 \mathrm{~A} 6$ and the blot developed with anti-mouse antibodies conjugated with alkaline phosphatase and an alkaline phosphatase conjugate-substrate kit (Bio-Rad).

Immunogold labelling and electron microscopy. Bacterial cells from 24-h-old TSA or TSB cultures were suspended in PBS at an $\mathrm{OD}_{620}$ of 1.0 , mixed with an equal volume of hybridoma 6A6 culture fluid, and incubated at $4^{\circ} \mathrm{C}$ overnight. Cells then were washed three times in PBS, suspended in $200 \mu \mathrm{l}$ of PBS, and $15 \mu \mathrm{l}$ of gold beads conjugated with goat-antimouse immunoglobulin $\mathrm{G}$ and immunoglobulin $\mathrm{M}$ (IgG+IgM; Bio/Can Scientific, Mississagua, ON, Canada) was added. The mixture was incubated for $1 \mathrm{~h}$ at room temperature with agitation, after which the cells were again washed three times with PBS and resuspended in $200 \mu \mathrm{l}$ of PBS. The treated cell suspension was air dried onto coppercoated electron microscope grids at 25 $\mu \mathrm{l} /$ grid. After staining with $1 \%$ phosphotungstic acid, grids were viewed using a Hitachi 650 transmission electron microscope.

PCR. For pure cultures of bacteria, cells grown overnight in $1 \mathrm{ml}$ of TSB were pelleted and resuspended in an extraction buffer containing $10 \mathrm{mM}$ Tris $\mathrm{HCl}(\mathrm{pH}$
7.8), $25 \mathrm{mM}$ EDTA, and 2\% sodium dodecyl sulfate and incubated for $15 \mathrm{~min}$ at $60^{\circ} \mathrm{C}$. Plant samples were macerated at 0.5 $\mathrm{g} /$ sample, lyophilized, then resuspended in the same extraction buffer but supplemented with $10 \mu \mathrm{g} / \mathrm{ml}$ of Proteinase K (6). Plant samples were incubated for $3 \mathrm{~h}$ at $60^{\circ} \mathrm{C}$ in extraction buffer before proteins were precipitated from solution by the addition of 7.5 $\mathrm{M}$ ammonium acetate and their subsequent removal by centrifugation. DNA was precipitated from the supernatant by the addition of an equal volume of isopropanol and incubation at $-20^{\circ} \mathrm{C}$ for $2 \mathrm{~h}$. The DNA was collected by centrifugation, washed with $70 \%$ ethanol, and dissolved in buffer (pH 7.8) containing $10 \mathrm{mM}$ Tris and 1 mM EDTA.

PCR was carried out using primers ADE1 and ADE2 directed to pectate lyase gene sequences but using reaction conditions modified from those published (19). Sample DNA was added at $1 \mu \mathrm{l} /$ sample to the reaction mixture containing $1.0 \mu \mathrm{M}$ of each primer, $0.2 \mathrm{mM}$ dNTPs, $0.2 \%$ skim milk (7), and 1.5 units of Gold Taq-polymerase (Bio/Can Scientific) in a total volume of $25 \mu \mathrm{l}$. The reaction was carried out in a Thermolyne Amplitron II thermocycler as follows: initial denaturation for 4 min at $94^{\circ} \mathrm{C}$, followed by 34 cycles of denaturation at $94^{\circ} \mathrm{C}$ for $1 \mathrm{~min}$, annealing at $67^{\circ} \mathrm{C}$ for $1 \mathrm{~min}$, and extension at $72^{\circ} \mathrm{C}$ for $1 \mathrm{~min}$. The final extension reaction at $72^{\circ} \mathrm{C}$ was run for $5 \mathrm{~min}$. PCR products were separated on a $2 \%$ agarose gel stained with ethidium bromide and visualized under ultraviolet light.

Plant samples. In experiments to test sensitivity and specificity of serological and PCR tests, potato tubers were spiked with cells of $E$. chrysanthemi strain NCPPB3530 from a pure culture. Bacterial cells were suspended to give an $\mathrm{OD}_{620}$ of 1.0 , and $1 \mathrm{ml}$ from each dilution of a 10fold series was added to $0.5 \mathrm{~g}$ of macerated potato tissue.

To establish plants infected with $E$. chrysanthemi, tuber pieces containing a single eye were cut with a melon baller and vacuum infiltrated with $E$. chrysanthemi strain NCPPB3530 containing approximately $10^{6} \mathrm{CFU} / \mathrm{ml}$. Control seed pieces were infiltrated with either E. carotovora subsp. atroseptica strain 31 or PBS. Seed pieces were planted in a commercial pasteurized soil potting mix in pots $(2$ seed pieces/pot) and plants were grown at $22^{\circ} \mathrm{C}$ with a 16-h photoperiod in a plant growth room under containment. Plants were grown and observed for symptoms for 90 days and then harvested for testing. Approximately $1 \mathrm{~cm}$ of lower stem tissue and $0.5 \mathrm{~g}$ of tissue from the stolon end of progeny tubers were macerated and lyophilized for later use in the ELISA and PCR procedures.

\section{RESULTS}

Specificity of serological tests and PCR. The polyclonal antibody reacted with all E. chrysanthemi strains in ELISA

Table 2. Strains of heterologous bacteria tested for reaction with monoclonal antibody 6A6 and polymerase chain reaction (PCR)

\begin{tabular}{|c|c|c|c|}
\hline Strain $^{a}$ & Species & Absorbance in ELISA ${ }^{b}$ & $\mathbf{P C R}^{\mathrm{c}}$ \\
\hline PD2253 & Comamonas sp. & 0.101 & ND \\
\hline CEPD1 & E. carotovora subsp. atroseptica & 0 & - \\
\hline CEPD3 & E. carotovora subsp. atroseptica & 0 & - \\
\hline CEPD6 & E. carotovora subsp. atroseptica & 0 & - \\
\hline CEPD15 & E. carotovora subsp. atroseptica & 0 & - \\
\hline CEPD29 & E. carotovora subsp. betavasculorum & 0 & - \\
\hline CEPD9 & E. carotovora subsp. carotovora & 0.002 & - \\
\hline CEPD13 & E. carotovora subsp. carotovora & 0.032 & _- \\
\hline CEPD14 & E. carotovora subsp. carotovora & 0.002 & - \\
\hline CEPD21 & E. carotovora subsp. carotovora & 0.005 & - \\
\hline CEPD24 & E. carotovora subsp. carotovora & 0 & _- \\
\hline PD751 & E. carotovora subsp. carotovora & 0.013 & ND \\
\hline PD877 & E. carotovora subsp. carotovora & 0.044 & ND \\
\hline PD878 & E. carotovora subsp. carotovora & 0.036 & ND \\
\hline RS1878 & E. carotovora subsp. oderifera & 0.003 & - \\
\hline MG-SR92 & E. carotovora subsp. wasabiae & 0.009 & - \\
\hline CEPD7G & E. herbicola & 0.002 & _- \\
\hline CEPD65 & Pseudomonas aerofaciens & 0.001 & - \\
\hline CEPD70 & P. aerofaciens & 0.038 & - \\
\hline CEPD92 & P. aerofaciens & 0 & _- \\
\hline PD1117 & P. aerofaciens & 0.052 & ND \\
\hline PD1228 & P. fluorescens & 0.036 & ND \\
\hline PD1878 & P. putida & 0.111 & ND \\
\hline PD1799 & Pseudomonas sp. & 0.130 & - \\
\hline PD1798 & Pseudomonas sp. & 0.110 & - \\
\hline$\ldots$ & 52 unidentified saprophytes & 0.039 (mean) & $-($ all $)$ \\
\hline
\end{tabular}

${ }^{a}$ Cultures were obtained from several sources as follows: CEPD - Centre of Expertise for Potato Diseases, Charlottetown (strains formerly held at the Vancouver Research Station); RS - R. Samson, France; MG - M. Goto, Japan; PD - Plant Protection Service, Wageningen.

${ }^{\mathrm{b}}$ ELISA = enzyme-linked immunosorbent assay; tests were considered positive if the absorbance readings were three times that of negative control values.

${ }^{\mathrm{c}} \mathrm{ND}=$ not done $;-$ indicates no amplification detected . 
and immunofluorescence, but also cross reacted with most of the E. carotovora strains tested. Only four hybridomas produced antibodies that were specific for $E$. chrysanthemi in the initial screening. One of these, 6A6, produced the strongest signal-to-noise ratio in ELISA and was, therefore, selected for further study. None of the four monoclonal antibodies selected in the primary screen reacted with the outer membrane in immunofluorescence.

Monoclonal antibody 6A6 typed out as an $\mathrm{IgG}_{2 \mathrm{~b}}$ and, in ELISA, reacted with all strains of $E$. chrysanthemi from potato except for two strains, one of which was isolated from potato in Australia and the other of unknown origin (Table 1). It also reacted with 20 of the 36 E. chrysanthemi

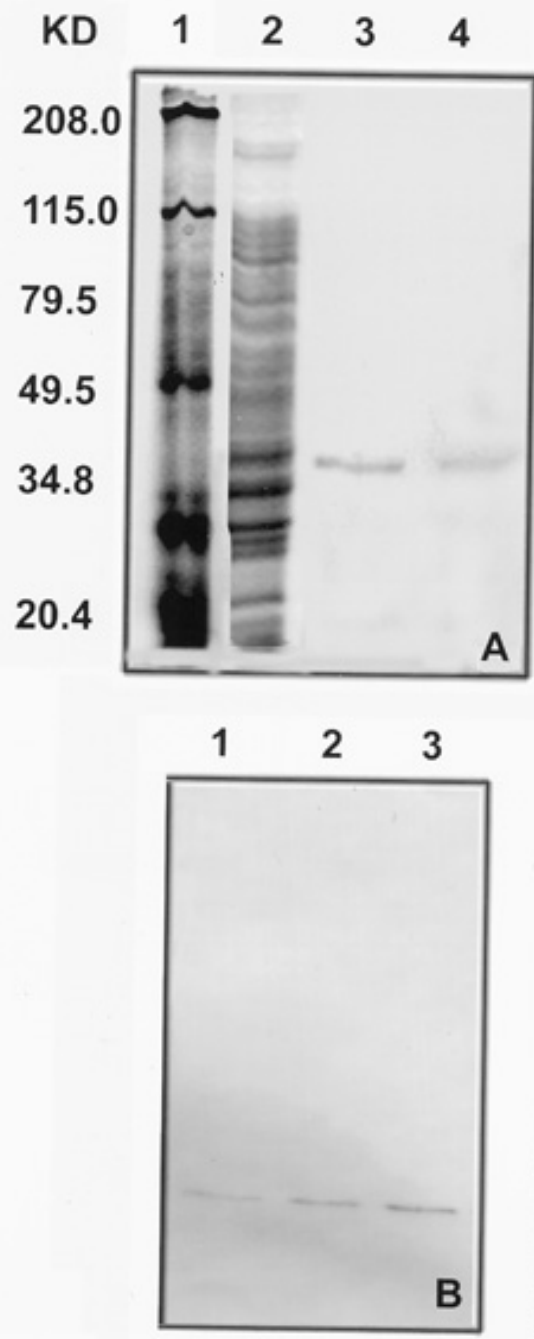

Fig. 1. Polyacrylamide gel electrophoresis and Western blot of whole-cell and fimbrial extracts of Erwinia chrysanthemi. (A) Lane 1 contains protein standards; lanes 2 and 3, coomassiestained gel of whole-cell preparation and fimbrial extract from strain NCPPB 3530, respectively; and lane 4, fimbrial extract from strain IPO 653. (B) Lane 1, Western blot of wholecell preparation; lane 2, fimbrial extract of strain NCPPB 3530; and lane 3, strain IPO 653 probed with monoclonal antibody $6 \mathrm{~A} 6$. strains isolated from other host plants (Table 1). Reactivity of strains was unrelated to biovar or host of origin. None of the 16 strains of E. carotovora or 62 other bacteria tested reacted in ELISA with 6A6 (Table 2). In comparison, all E. chrysanthemi strains that were tested, regardless of the host from which it was isolated, yielded a 420-basepair (bp) amplification product in PCR (Table 1). All of the heterologous strains of bacteria tested did not yield an amplification product in PCR (Table 2).

Sensitivity of ELISA and PCR. Sensitivity of ELISA was about $10^{7} \mathrm{CFU} / \mathrm{ml}$ when testing dilutions of pure cultures of E. chrysanthemi and with spiked tuber tissue. Use of the lysozyme buffer to suspend samples increased the absorbance of the positive samples in ELISA but did not significantly affect sensitivity. Sensitivity of PCR was $10^{2} \mathrm{CFU} / \mathrm{ml}$ for pure cultures and $10^{3} \mathrm{CFU} / \mathrm{ml}$ for spiked tuber tissue.

Antigen determination. The fimbrial extraction procedure yielded a single protein band in gel electrophoresis (Fig. 1A). In the Western blot of both the whole cell proteins and the fimbrial preparation, monoclonal $6 \mathrm{~A} 6$ reacted with a single band at approximately $40 \mathrm{kDa}$ (Fig. 1B). The negatively stained bacterial cell preparations observed by electron microscopy revealed the presence of filaments of variable length with a diameter of about $14 \mathrm{~nm}$ and with typical fimbrial morphology (Fig. 2). Selective attachment of gold beads to the fimbria-like structures was observed in preparations treated with monoclonal 6A6 and anti-mouse IgG antibodies conjugated to gold beads (Fig. 2).

Detection of $E$. chrysanthemi in potato tissue. A number of seed pieces inoculated with E. chrysanthemi failed to produce plants due to decay of the seed pieces. However, all those inoculated with $E$. carotovora subsp. atroseptica and buffer controls grew into apparently healthy plants. About $60 \%$ of the plants inoculated with $E$. chrysanthemi developed yellowing of the lower leaves, as is typical of $E$. chrysanthemi infections in the field. One plant developed decay in the lower portion of the stem but no blackleg-like discoloration was observed. Of the 14 stems grown from $E$. chrysanthemi-infected seed pieces, only 4 were positive in ELISA, although all but 2 stem samples were positive in PCR (Table 3). Of 28 progeny tubers tested from these plants, 1 developed decay symptoms and was positive in ELISA. A total of 6 additional symptomless tubers were also positive in ELISA, whereas a total of 17 tubers tested positive in PCR. The stems and progeny tubers tested from plants inoculated with E. carotovora subsp. atroseptica or buffer alone were all negative in ELISA and PCR tests for E. chrysanthemi (Table 3). These samples were also negative for E. carotovora subsp. atroseptica in ELISA.

\section{DISCUSSION}

The presence of non-flagellar appendages on certain pectolytic Erwinia spp. has been noted previously, but their function has not been studied $(3,15)$. These appendages were called "fimbriae," although this term is often restricted to those appendages involved in microbial adhesion, while the term "pili" is used for morphologically similar appendages involved in conjugative DNA transfer (20). In this study, we continue the practice of using the term fimbriae for such appendages of pectolytic Erwinia spp. of unknown function.

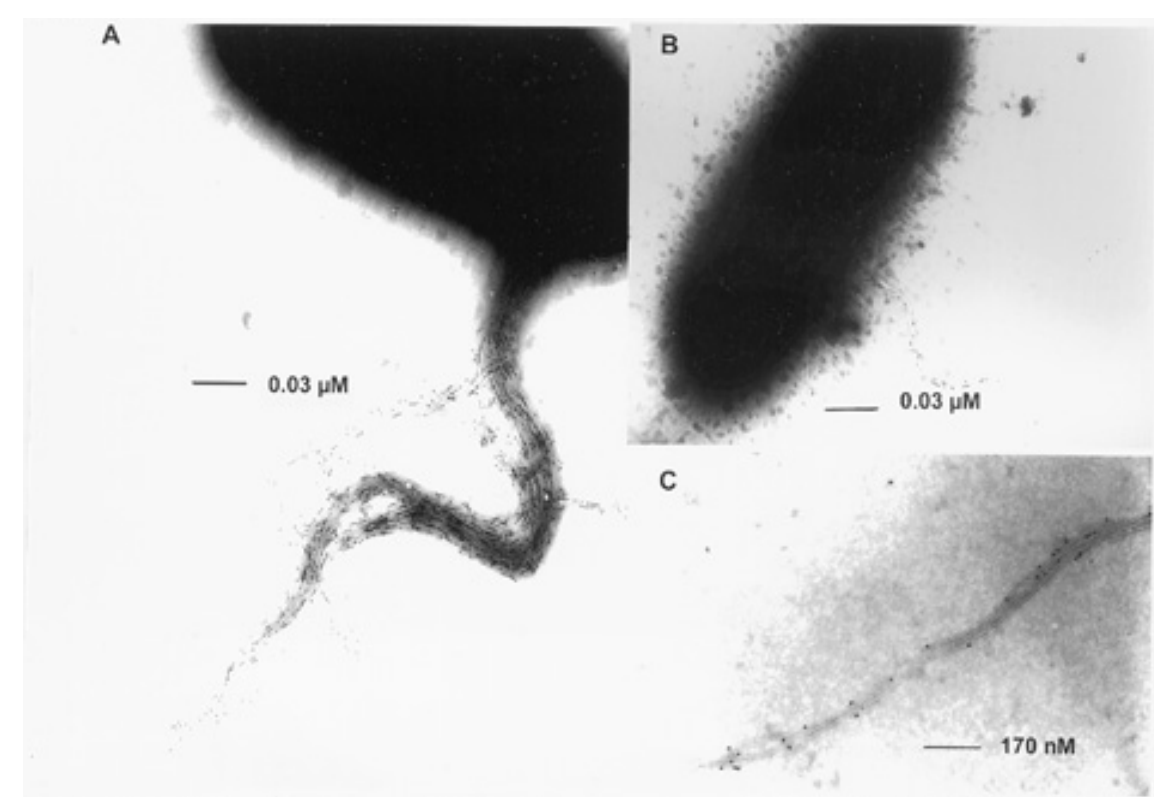

Fig. 2. Electron micrographs of immunogold-treated preparations of Erwinia chrysanthemi using monoclonal antibody 6A6. (A) Whole cell showing attached bundle of fimbriae, (B) whole cell showing single attached fimbria, and (C) high magnification of fimbriae. 
The fortuitous development of monoclonal antibodies to fimbrial antigens of $E$. chrysanthemi provided a serological probe that reacted with all the European potato isolates tested, as well as with many, but not all, strains isolated from other hosts. The electron micrographs (Fig. 2) provided evidence that the monoclonal antibody targeted a fimbrial epitope and is consistent with the reaction of a single protein band in the Western blot (Fig. 1). The E. chrysanthemi fimbrial diameter at $14 \mathrm{~nm}$ was about twice that reported for $E s$ cherichia coli pili, which are approximately $7 \mathrm{~nm}$ wide (9), and the molecular weight of the E. chrysanthemi fimbrial subunit at $40 \mathrm{kDa}$ was considerably greater than that reported for other enteric fimbrial resistant and type-I fimbrillins of E. carotovora subsp. carotovora were 18 and 16.5 $\mathrm{kDa}$, respectively (15). Fimbrillins in the $30-$ to $40-\mathrm{kDa}$ range have previously been reported for other non-enteric bacteria, such as Bacterioides gingivalis, however (30). It is also noteworthy that the lysozyme-based extraction buffer used to solubilize lipopolysaccharide from the outer membrane of gram-negative bacteria to enhance reaction in ELISA tests also enhanced the ELISA test targeting a fimbrial antigen (14). The lysozyme treatment probably releases various outer-membraneassociated components in addition to lipopolysaccharide by its action on the peptidoglycan structure of the bacterial membrane.

It is not known whether these fimbriae play a role in plant pathogenesis as adhesins or in another function, but their universal presence on potato strains may suggest a role in host invasion. It has been shown that pili (fimbriae) play a role in the attachment of Pseudomonas syringae pv. phaseolicola, the halo blight pathogen of bean, to stomata (21). Alternatively, the consistent presence of fimbriae on potato strains may suggest that strains of E. chrysanthemi on potato in Europe are of clonal origin as a result of a limited number of introductions from an external source. The proteins (9). For example, the mannose-

failure of the Australian and other potato strain of unknown origin (Table 1) to react with monoclonal $6 \mathrm{~A} 6$ could be due to the presence of another serological type or absence of fimbriae altogether, as suggested by the lack of a protein band in the one fimbrial extraction we carried out on one Australian isolate (data not shown). A previous monoclonal antibody produced to the lipopolysaccharide of another E. chrysanthemi potato strain from Europe also failed to react with several potato strains from Australia (S. H. De Boer and J. M. van der Wolf, unpublished data), suggesting that at least some Australian strains differ serologically from those in Europe.

Although the reaction of monoclonal 6A6 with a portion of strains in the $E$. chrysanthemi species does not contribute significantly to the subspecific classification of the species, its universal reaction with potato isolates from Europe suggests that it may be useful for diagnostic and detection work. Because E. chrysanthemi lacks a species-specific lipopolysaccharide, an extracellular protein is a logical alternate target for a serological test. Fimbrial antigens are a good target for the ELISA test because they occur in high copy number and are readily freed from cells with mild treatments. Whether fimbriae are consistently produced by $E$. chrysanthemi when associated with potato tissue has not been fully explored. Some of the samples from plant tissue infected with $E$. chrysanthemi were positive in ELISA (Table 3), but many were negative, even though the positive PCR test suggested that the bacterium was present. The possibility of a false-positive PCR reaction due to amplification of pectolytic soil bacteria was not entirely ruled out, although all of the control samples were negative. Rather than being due to the lack of production of fimbriae, the negative ELISA results could also have been due to low populations of the bacterium because sensitivity of ELISA was 100 - to 1,000 -fold less than PCR. The difference in sensitivity between ELISA and PCR is probably due to the inherent differences in the tests (10). Fur-

Table 3. Reaction of stem and progeny tuber tissue samples from plants grown from seed inoculated with Erwinia chrysanthemi, E. carotovora subsp. atroseptica, or buffer, in enzyme-linked immunosorbent assay (ELISA) and polymerase chain reaction (PCR) tests to detect the presence of E. chrysanthemi

\begin{tabular}{llccc}
\hline Inoculation, tissue & Symptom & $\begin{array}{c}\text { No. of } \\
\text { samples }\end{array}$ & $\begin{array}{c}\text { No. positive } \\
\text { in ELISA }\end{array}$ & $\begin{array}{c}\text { No. positive } \\
\text { in PCR }\end{array}$ \\
\hline E. chrysanthemi & Soft rot & 1 & 0 & \\
Stem & Leaf yellowing & 9 & 2 & 1 \\
Stem & None & 4 & 2 & 9 \\
Stem & Decay & 1 & 1 & 1 \\
Tuber & None & 27 & 6 & 16 \\
$\quad \begin{array}{l}\text { Tubers } \\
\text { E. carotovora subsp. atroseptica }\end{array}$ & None & 20 & 0 & 0 \\
Stem & None & 33 & 0 & 0 \\
$\quad$ Tuber & & & & \\
Buffer & None & 10 & 0 & 0 \\
Stem & None & 18 & 0 & 0 \\
Tuber & & &
\end{tabular}

ther studies on naturally infected potato tissue is required to determine whether the ELISA test targeting E. chrysanthemi fimbriae will have adequate sensitivity to detect bacterial populations of epidemiological significance. An alternate approach would be enrichment ELISA, which could significantly enhance sensitivity (10). In any case, monoclonal 6A6 will be useful for rapid diagnosis of stem wet rot and slow wilt disease in potato and preliminary identification of $E$. chrysanthemi potato isolates. Only additional research will determine whether the monoclonal will be a useful tool for routine indexing of seed potatoes for the presence of this pathogen.

\section{LITERATURE CITED}

1. Boccara, M., Vedel, R., Lalo, D., Lebrun, M.H., and Lafay, F. F. 1991. Genetic diversity and host range in strains of Erwinia chrysanthemi. Mol. Plant-Microbe Interact. 4:293299.

2. Cappaert, M. R., Powelson, M. L., Franc, G. D., and Harrison, M. D. 1988. Irrigation water as a source of inoculum of soft rot erwinias for aerial stem rot of potatoes. Phytopathology 78:1668-1672.

3. Christofi, N., Wilson, M. I., and Old, D. C. 1979. Fimbriae and haemagglutinins in erwinias of the carotovora group. J. Appl. Bacteriol. 46:179-183.

4. Cother, E. J., and Powell, V. 1983. Physiological and pathological characteristics of Erwinia chrysanthemi isolates from potato tubers. J. Appl. Bacteriol. 54:37-43.

5. De Boer, S. H. 1990. Immunofluorescence for bacteria. Pages 295-298 in: Serological Methods for Detection and Identification of Viral and Bacterial Plant Pathogens-A Laboratory Manual. R. Hampton, E. Ball, and S. De Boer, eds. APS Press, St. Paul. MN.

6. De Boer, S. H., and Ward, L. J. 1995. PCR detection of Erwinia carotovora subsp. atroseptica associated with potato tissue. Phytopathology 85:854-858.

7. De Boer, S. H., Ward, L. J., Li, X., and Chittaranjan, S. 1995. Attenuation of PCR inhibition in the presence of plant compounds by addition of BLOTTO. Nucleic Acids Res. 23:2567-2568.

8. Dickey, R. S. 1979. Erwinia chrysanthemi: a comparative study of phenotypic properties of strains from several hosts and other Erwinia species. Phytopathology 69:324-329.

9. Eisenstein, B. 1987. Fimbriae. Pages 84-90 in: Escherichia coli and Salmonella typimurium Cellular and Molecular Biology. F. C. Neidhardt, ed. ASM, Washington, DC.

10. Frechon, D., Exbrayat, P., Helias, V., Hyman, L. J., Llop, P., Lopez, M. M., Payet, N., Perombelon, M. C. M., Toth, I. K., Van Beckhoven, J. R. C. M., van der Wolf, J. M., and Bertheau, Y. 1998. Evaluation of a PCR kit for the detection of Erwinia carotovora subsp. atroseptica on potato tubers. Potato Res. 41:163-173.

11. Heckels, J. E., and Virji, M. 1988. Separation and purification of surface components. Pages 67-135 in: Bacterial Cell Surface Techniques. I. Hancock and I. Poxton, eds. John Wiley and Sons, New York.

12. Janse, J. D., and Ruissen, M. A. 1988. Characterizaton and classification of Erwinia chrysanthemi strains from several hosts in the Netherlands. Phytopathology 78:800-808.

13. Janse, J. D., and Scheepens, T. 1989. Further biochemical and serological classification of Erwinia chrysanthemi strains. Pages 779-787 in: Proc. 7th Int. Conf. Plant Pathogenic Bac- 
teria. Budapest, Hungary. Z. Klement, ed. Akademiai Kiado, Budapest.

14. Jones, J. B., Somodi, G. C., and Scott, J. W. 1997. Increased ELISA sensitivity using a modified extraction buffer for detection of Xanthomonas campestris pv. vesicatoria in leaf tissue. J. Appl. Microbiol. 83:397-401.

15. Korhonen, T. K., Kalkkinen, N., Haahtela, K., and Old, D. C. 1987. Characterization of type 1 and mannose-resistant fimbriae of Erwinia spp. J. Bacteriol. 169:2281-2283.

16. Lelliott, R. A. 1956. Slow wilt of carnation caused by a species of Erwinia. Plant Pathol. 5:19-23.

17. Lumb, V. M., and Perombelon, M. C. M. 1986. Studies of a wilt disease of the potato plant in Israel caused by Erwinia chrysanthemi. Plant Pathol. 35:196-202.

18. McLaughlin, R. J., and Chen, T. A. 1990. ELISA methods for plant pathogenic prokaryotes. Pages 197-204 in: Serological Methods for Detection and Identification of Viral and Bacterial Plant Pathogens-A Laboratory Manual. R. Hampton, E. Ball, and S. De Boer, eds. APS Press, St. Paul. MN.

19. Nassar, A., Darrassee, A., Lemattre, M., Kotoujansky, A., Dervin, C., Vedel, R., and Bertheau, Y. 1996. Characterization of Er- winia chrysanthemi by pectinolytic isozyme polymorphism and restriction fragment length polymorphism analysis of PCR-amplified fragments of pel genes. Appl. Environ. Microbiol. 62:2228-2235.

20. Ottow, J. C. G. 1975. Ecology, physiology and genetics of fimbriae and pili. Annu. Rev. Biochem. 29:79-108.

21. Romanchuck, M., and Bamford, B. H. 1986. The causal agent of halo blight in bean, Pseudomonas syringae pv. phaseolicola, attaches to stomata via its pili. Microbial Pathogenesis 1:139-148.

22. Samson, R. 1973. Les Erwinia pectinolytiqes. II. Recherches sur les antigenes somatiques d'Erwinia carotovora var. chrysanthemi (Burkholder) Dye 1969. Ann. Phytopathol. 5:377-388.

23. Samson, R., Poutier, F, Sailly, M., and Jouan, B. 1987. Caracterisation des Erwinia chrysanthemi isolees de Solanum tubersosum et d'autres plantes-hotes selon les biovars et serogroupes. EPPO Bull. 17:11-16.

24. Serfontein, S., Logan, C., Swanepoel, A. E., Boelema, B. H., and Theron, D. J. 1991. A potato wilt disease in South Africa caused by Erwinia carotovora subspecies carotovora and E. chrysanthemi. Plant Pathol. 40:382-386.
25. Stead, D. 1996. Bacterial diseases of potatoes-future problems? Proc. Crop Prot. N. Br. 1996:303-311.

26. Tominaga, T., and Ogasawara, K. 1979. Bacterial stem rot of potato caused by Erwinia chrysanthemi. Ann. Phytopathol. Soc. Jpn. 45:474-477.

27. Turkensteen, L. J. 1996. Blackleg, stem wet rot and aerial stem rot. Pages 62-65 in: Potato Diseases: Diseases, Pest and Defects. D. E. van der Zaag, ed. NIVAA, Den Haag, Netherlands.

28. van der Wolf, J. M. 1994. Evaluation of serological methods for detection of Erwinia chrysanthemi in potato peel extracts. Ph.D. thesis. Rijksuniversiteit, Leiden, The Netherlands.

29. van der Wolf, J. M., Van Beckhoven, J. R. C. M., De Boef, E., and Roozen, H. J. M. 1993 Serological characterization of fluorescent Pseudomonas strains cross-reacting with antibodies against Erwinia chrysanthemi. Neth. J. Plant Pathol. 99:51-60.

30. Yoshimura, F., Takahashi, K., Nodasaka, Y., and Suzuki, T. 1984. Purification and characterization of a novel type of fimbriae from the oral anaerobe Bacterioides gingivalis. $\mathrm{J}$ Bacteriol. 160:949-957. 